\title{
Production of bio-diesel from Pithraj (Aphanamixis polystachya) seed oil
}

\author{
S. K. Banik ${ }^{1}$, M. A. Rouf ${ }^{1 *}$, M. Khanam ${ }^{1}$, M. S. Islam ${ }^{1}$, T. Rabeya $^{1}$, F. Afrose ${ }^{2}$ and D. Saha ${ }^{2}$ \\ ${ }^{1}$ Institute of Fuel Research and Development, BCSIR, Dr. Qudrat-i- Khuda Road, Dhanmondi Dhaka-1205. \\ ${ }^{2}$ Department of Applied Chemistry and Chemical Engineering, University of Dhaka, Bangladesh.
}

\begin{abstract}
The Pithraj seed has been collected from Gazipur district, Bangladesh. The oil from the seed was extracted by using Soxhlet apparatus using petroleum ether extraction method. Maximum yield of oil was found to be $50 \%$ when the process was carried out for 2.5 hours. The physicochemical properties of the extracted oil were studied. The properties of the oil reveal that the oil corresponds to diesel except acid value and sulphur content. The optimum conditions of the transesterification of the oil was $40 \%$ ethanol and $0.45 \% \mathrm{KOH}$ at $75{ }^{\circ} \mathrm{C}$ for 1.5 hours. The optimum yield was more than $95 \%$.
\end{abstract}

Keywords: Pithraj seed; Biodiesel; Transesterification

\section{Introduction}

The current fossil fuel-based economy is not sustainable because of environmental impacts, economic dependence and energy security issues. Today $86 \%$ of the world energy consumption and almost $100 \%$ of the energy needed in the transportation sector is met by fossil fuels (Dorian et al., 2006). The production and consumption of fossil fuels have caused the environmental damage by increasing the $\mathrm{CO}_{2}$ concentration in the atmosphere (Westermann et al., 2007). One-fifth of the global $\mathrm{CO}_{2}$ emissions are created by transport sector (Goldemberg, 2008), which accounts for some $60 \%$ of global oil consumption (Anonymous, 2008). Around the world there were about 806 million cars and light trucks on the road in 2007 (Anonymous, 2007). These numbers are projected to increase by 1.3 billion by 2030 and to other 2 billion vehicles by 2050 (Anonymous, 2004). These growths will affect the stability of ecosystems and global climate as well as global oil reserves (Balat, 2009). There are active research programs to reduce on fossil fuels by use of

alternative and sustainable fuel sources and thus to increase the time over which fuel will still be available (Namasivayam et al., 2010). As an alternative to petroleum based transportation fuels, bio-fuels can help to reinforce energy security and reduce the emissions of both green house gases (GHSs) and urban air pollutants.

At present bio-diesel is a suitable renewable substitute for petroleum based diesel. Pithraj seed oil is easily available in many parts of the world including Bangladesh and is very cheap compared to other sources. The non-edible renewable pithraj (Aphanamixis polystacya) oil can play a vital role in the cultivation of alternative substitute to diesel fuel. The climate and soil condition of Bangladesh is also suitable for the cultivation of this plant. Literature shows that the yield of oil from pithraj seed is about $40-45 \%$ which is higher compared to other non-edible seeds like rubber seed $(31.8 \%)$ and others (Gui et al., 2008). If the developed process is scaled up to commercial levels, then excellent business opportunity will be offered by the bio-diesel and could be a major step towards the creation of an eco-friendly transportation fuel. By increasing pithraj plantation in Bangladesh, we can meet our demand. Finally, the by-product of transesterification can also be used in the soap industry. The present investigation includes: preparation of bio-diesel from pithraj seed oil, optimization of different parameters for maximum bio-diesel production, determination of properties of pithraj seed oil and prepared bio-diesel and comparison of the fuel properties of conventional diesel with prepared bio-diesel.

\section{Materials and methods}

\section{Oil Extraction}

Pithraj seeds were purchased from local market of Gazipur, Bangladesh and dried properly in the sun for several hours and then grinded. Then ground powder was screened to separate the coarse ones and which was again grinded for homogeneous. Extraction of oil from the powders using petroleum ether as solvent was then carried out in Soxhlet apparatus at 60-80 ${ }^{\circ} \mathrm{C}$ and at reflux temperature of solvent. After extraction of oil, the solvent petroleum ether was separated and solventfree oil was obtained. The oil was found to be viscous and dark brown in color. The oil was directly used as main raw material for bio-diesel production. The properties of the oil were then determined and recorded.

\footnotetext{
*Corresponding author. e-mail: roufmd@yahoo.com
} 


\section{Determination of the fatty acids and fats}

The acid value of the reaction mixture was determined by a standard acid-base titration method using a standard solution of 1.0 M KOH solution. Biodiesel productions prior to transesterification, acid esterification of the oil was required to reduce $(\sim 57 \%)$ the free fatty acid. The ethanol and catalyst conc. $\mathrm{H}_{2} \mathrm{SO}_{4}$ mixture was then charged into a 2-neck closed reaction vessel and the raw oil was added. The reaction temperature was around $70{ }^{\circ} \mathrm{C}$ at agitation rate $400 \mathrm{rpm}$ for 2 hours. After completion of transesterification, ethyl ester was separated from mixture of ethyl ester and glycerin. The mixture was taken in a separating funnel and left for 16 hours. The mixture was separated in two layers, bio-diesel as the top layer and glycerin as bottom layer. Glycerin layer was withdrawn and required product was obtained. Washing of bio-diesel is necessary to remove the soluble components. Hot water was sprayed on top of the bio-diesel. Then it was allowed to settle down. The product was dried using a vacuum evaporator at $80{ }^{\circ} \mathrm{C}$ and pressure was $180 \mathrm{~atm}$. pressure. After drying the product became clear. After purification of bio-diesel, the fuel properties of bio-diesel were determined by laboratory method. To determine the properties of bio-diesel produced from Pithraj seed oil, different ISO standard methods were used.

\section{Other parameters}

All the parameters for fuel properties were estimated by ISO standard methods such as density at $15{ }^{\circ} \mathrm{C}$ by IP $131 / 57$ method, colour index by ASTM \& DIN 51900 method, kinematic viscosity by viscometer $73 / 53$ method, pour point by ASTM D 97-57, IP 15/55 method, flash point by ASTM D 93-62 method, sulphur content by IP 61/59 method, water content by IP $74 / 57$ method, carbon residue by ASTM D 189-65 method, ash content by IP 4/58 method, acid value by IP 1/58 method, calorific value by bomb calorimeter IP 12/58, corrosion by IP $154 / 59$, fire point by IP $35 / 42$ methods.

\section{Results and discussion}

\section{Optimization to extraction of oil}

After extraction of Pithraj seed oil by solvent extraction method, optimization of the method was performed. (Table I), it is clear that, higher percentage of oil per gram of sample was obtained when the extraction process was conducted with an excess of solvent. In addition, the extraction also requires an excess of time. An optimized point considering both amount of solvent and time for maximal yield of oil was obtained. when $600 \mathrm{~mL}$ of solvent was used and the process was carried out for 2.5 hours.

Table II. Properties of the pithraj seed oil

\begin{tabular}{|c|c|}
\hline Parameters & seed oil \\
\hline Color Index & 0.5 \\
\hline Density @15 ${ }^{\circ} \mathrm{C}, \mathrm{g} / \mathrm{cc}$ & 0.8473 \\
\hline Kinematic Viscosity @40 ${ }^{\circ} \mathrm{C}, \mathrm{cSt}$ & 2.0304 \\
\hline Kinematic Viscosity @ $100{ }^{\circ} \mathrm{C}$, cSt & 0.9676 \\
\hline Pour Point, ${ }^{\mathrm{O}} \mathrm{C}$ & $<-18$ \\
\hline Flash Point, ${ }^{\mathrm{o}} \mathrm{C}$ & 30 \\
\hline Fire Point, ${ }^{\circ} \mathrm{C}$ & 40 \\
\hline Sulfur Content, $\%(\mathrm{w} / \mathrm{w})$ & 8.091 \\
\hline Cetane Number & - \\
\hline Water Content, \% (v/v) & Nil \\
\hline Carbon Residue, \% (w/w) & 0.0593 \\
\hline Ash Content, \% (w/w) & 0.00255 \\
\hline Acid Value, mg $\mathrm{KOH} / \mathrm{g}$ & 56.4 \\
\hline Calorific Value, $\mathrm{kcal} / \mathrm{kg}$ & 9368.3463 \\
\hline
\end{tabular}

Table I. Extraction of pithraj seed oil by solvent extraction method

\begin{tabular}{|c|c|c|c|c|c|c|}
\hline $\begin{array}{l}\text { Sample } \\
\text { weight } \\
\text { (g) }\end{array}$ & $\begin{array}{c}\text { Solvent } \\
(\mathrm{mL})\end{array}$ & $\begin{array}{c}\text { Solvent } \\
\text { recovered } \\
(\mathrm{mL})\end{array}$ & $\begin{array}{c}\text { Oil } \\
\text { extracted } \\
(\mathrm{g})\end{array}$ & $\begin{array}{c}\text { Oil } \\
\text { volume } \\
(\mathrm{mL})\end{array}$ & $\begin{array}{c}\text { Oil } \\
\text { content } \\
\left(\begin{array}{ll}\text { wt } \%)\end{array}\right.\end{array}$ & $\begin{array}{c}\text { Time } \\
\text { (minutes) }\end{array}$ \\
\hline 87.0030 & 800 & 420 & 21.6689 & 23.95 & 24.91 & 60 \\
\hline 85.4241 & 800 & 345 & 28.1671 & 31.13 & 32.97 & 60 \\
\hline 99.7364 & 600 & 320 & 44.2030 & 48.86 & 44.32 & 60 \\
\hline 85.6348 & 600 & 235 & 43.1432 & 47.69 & 50.38 & 150 \\
\hline 36.7771 & 500 & 370 & 14.7100 & 16.26 & 39.98 & 150 \\
\hline 45.7945 & 400 & 355 & 21.9800 & 24.29 & 48.00 & 150 \\
\hline 29.0465 & 300 & 170 & 14.1663 & 15.66 & 48.77 & 150 \\
\hline
\end{tabular}




\section{Physicochemical properties of Pithraj seed oil}

After extraction of oil from Pithraj seeds, the physicochemical properties of the oil were determined according to the standard procedure. Table II. shows the properties of the Pithraj seed oil.

\section{Effects of different factors on production of biodiesel}

Bio-diesel was produced using Pithraj seed oil by transesterification process. The yield of bio-diesel depends on a number of factors which affect the transesterification reaction.

\section{Effect of change of ethanol to product yield}

The effect of change of molar ratio of ethanol to oil was optimized. The amount of catalyst $\mathrm{KOH}$ was kept constant at $1 \%$ of oil. The temperature was fixed at $60-65^{\circ} \mathrm{C}$. Under this condition the percentage of ethanol was varied to get maximum yield of biodiesel (Table III).

Table III. The effect of variation of oil to ethanol ratio on product yield

\begin{tabular}{ccccc}
\hline $\begin{array}{c}\text { pithraj oil } \\
(\mathrm{g})\end{array}$ & $\begin{array}{c}\text { Ethanol } \\
(\% \text { of oil })\end{array}$ & $\begin{array}{c}\text { KOH } \\
(\% \text { of oil })\end{array}$ & $\begin{array}{c}\text { Product } \\
(\mathrm{g})\end{array}$ & $\begin{array}{c}\text { Yield } \\
(\%)\end{array}$ \\
\hline 5.00 & 20 & 1 & 3.163 & 63.26 \\
5.10 & 25 & 1 & 3.867 & 75.82 \\
5.00 & 30 & 1 & 4.321 & 86.42 \\
5.00 & 35 & 1 & 4.678 & 93.55 \\
5.10 & 40 & 1 & 5.036 & 98.75 \\
5.04 & 45 & 1 & 4.192 & 83.17 \\
\hline
\end{tabular}

It is found that with the increase of ethanol on percent weight of oil, the percent yield of biodiesel also increases up to about $99 \%$. Further addition of ethanol the percent yield of biodiesel decreased. The optimum amount of ethanol to get

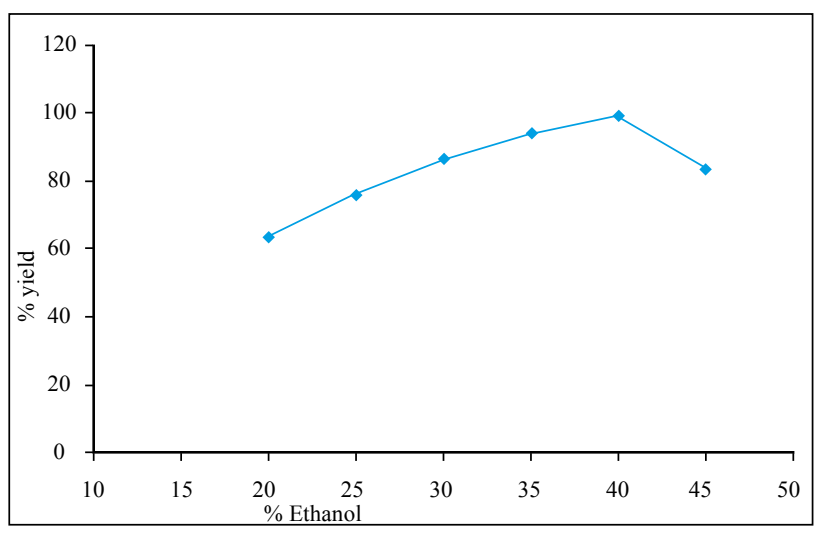

Fig. 1. Effect of variation of ethanol percent on product yield maximum yield of biodiesel was about $40 \%$ of the weight of oil taken. The optimization of ethanol for maximum biodiesel yield is shown in (Fig. 1).

\section{Effect of variation of catalyst to product yield}

To optimize the amount of $\mathrm{KOH}$ the percentage of ethanol was maintained at $40 \%$ of ethanol on the wt $\%$ of oil taken. The temperature was also kept constant. In this condition, the reaction were carried out with $\mathrm{KOH}$ catalyst at concentrations

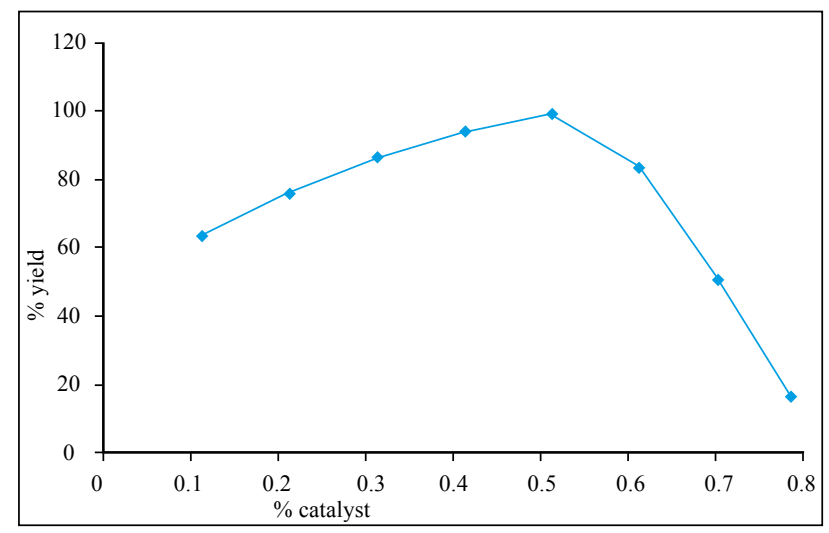

Fig. 2. Effect of change of catalyst percent on yield of Bio-diesel

$0.15,0.25,0.35,0.45,0.55,0.65$ and $0.75 \%$ in order to determine optimum condition for the biodiesel production from the oil. The maximum yield of biodiesel was found to be at $0.45 \% \mathrm{KOH}$ concentration as shown in (Fig. 2).

\section{Effect of variation of temperature on product yield}

For the optimization of temperature, the percentage of catalyst and ethanol under maximum liquid condition considered constant and the temperature were found to be varied. The biodiesel production by transesterification was also studied at $55,60,65,70,75$ and $80{ }^{\circ} \mathrm{C}$. The maximum yield of bio-diesel was obtained when the temperature of reaction

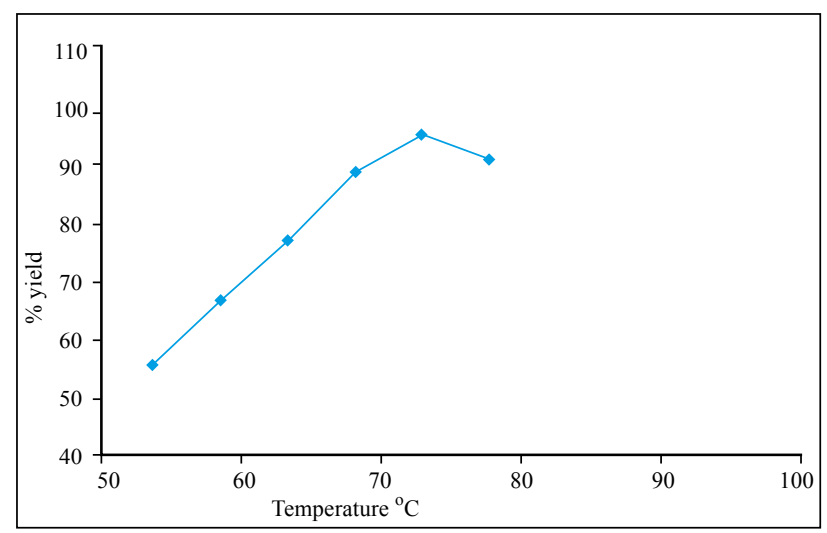

Fig. 3. Effect of Temperature on \% yield of Bio-diesel 
system was maintained at $75{ }^{\circ} \mathrm{C}$ which is just below the boiling point of ethanol as shown in (Fig. 3). Further increase of temperature caused the yield to decrease because the ethanol started to boil and became separated from the reaction system.

\section{Effect of variation of reaction time on product yield}

All variables except reaction time were kept constant in their optimum value. The transesterification reaction was continued for different period of time such as 30, 60, 90 and 120

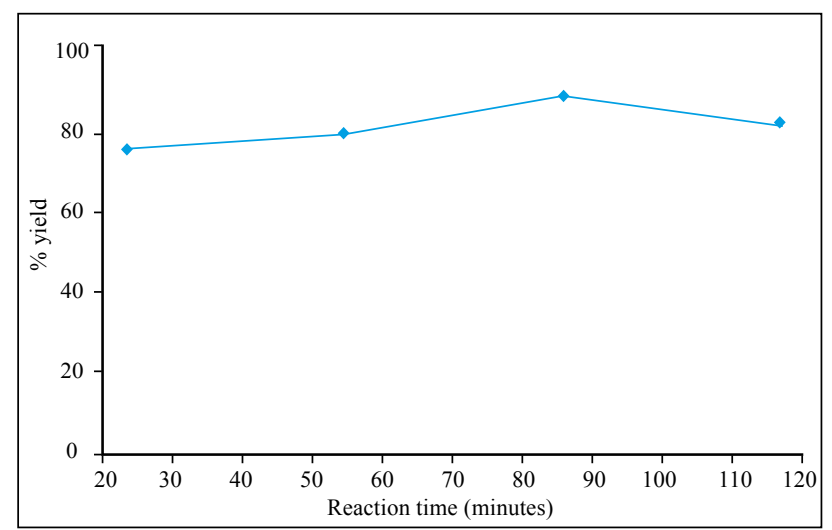

Fig. 4. Effect of Reaction time on the \% yield of Bio-diesel

minutes respectively. Then the product yield was observed. The result of this optimization is shown in (fig. 4). It is found that with the increase of duration of reaction, the yield of bio-diesel shows increasing phenomena, eventually increase to give maximum yield about $94 \%$. when reaction took one 1.5 hours.

Although, further reaction time should raise the conversion percentage, it actually caused to decrease in yield \%. The reason might be prolonged time of stirring, that cause problem in phase separation. Moreover, the longer duration of a reaction process was not considered feasible.

The optimum conditions for biodiesel production from pithraj seed oil can be summarized as follows: The overall transesterification reaction requires about $40 \%$ of ethanol on the basis oil taken; catalyst $(\mathrm{KOH})$ with a concentration is $0.45 \%$ of the oil and a fair reaction time of 1.5 hours at a temperature of $75{ }^{\circ} \mathrm{C}$ with moderate stirring rate. The optimum yield is more than $95 \%$.

\section{Characteristics of bio-diesel from Pithraj seed oil}

The bio-diesel obtained was then characterized by the established methods. Table IV describes the fuel characteristics of bio-diesel from pithraj seed and also gives a comparison of obtained bio-diesel with conventional diesel fuel.

\section{FTIR analysis}

To determine the functional group of extracted pithraj seed oil, FTIR Spectroscopic analysis method was employed (Fig. 5.). Appropriate quantities of $\mathrm{KBr}$ and pithraj seed oil (in the ratio of 100:0.1) were mixed by grinding in an agate mortar

Table IV. Comparison of the fuel properties of obtained bio-diesel and conventional diesel

\begin{tabular}{|c|c|c|c|}
\hline \multirow{2}{*}{$\begin{array}{l}\text { Test Parameter } \\
\text { Density at } 15^{\circ} \mathrm{C} \mathrm{g} / \mathrm{mL}\end{array}$} & \multicolumn{2}{|c|}{$\begin{array}{l}\text { Bio-diesel standard } \\
\text { Prepared bio-diesel }\end{array}$} & \multirow{2}{*}{$\begin{array}{l}\begin{array}{l}\text { Commercial } \\
\text { bio-diesel }\end{array} \\
0.8445\end{array}$} \\
\hline & 0.88 & 0.873 & \\
\hline Kinematic Viscosity@ $40{ }^{\circ} \mathrm{C}, \mathrm{cSt}$ & $1.9-6.0$ & 2.416 & 6.06 \\
\hline Kinematic Viscosity@ $100^{\circ} \mathrm{C}, \mathrm{cSt}$ & - & 1.764 & - \\
\hline Pour Point, ${ }^{\circ} \mathrm{C}$ & $-15-16$ & -8 & -10 \\
\hline Flash Point, ${ }^{\circ} \mathrm{C}$ & $100-170$ & 153 & 70 \\
\hline Acid Value, mg KOH/g & $0.80 \max$ & 0.58 & 0.34 \\
\hline Sulphur Content, \% (w/w) & 0.5 & 1.5 & 0.905 \\
\hline Cetane Number & $48-60$ & 51 & 51 \\
\hline Water Content, \% (v/v) & 0.05 & nil & Nil \\
\hline Carbon Residue, \% (w/w) & $0.05 \max$ & 0.82 & - \\
\hline Ash Content, \% (w/w) & $0.02 \max$ & Nil & - \\
\hline Calorific Value, kcal/kg & 9231 & 10027 & 10664 \\
\hline
\end{tabular}

and pellets were made with about $100 \mathrm{mg}$ mixture. FTIR spectra were recorded with FTIR 8400S Shimadzu Spectrophotometer in the range of $4000-400 \mathrm{~cm}^{-1}$. Resolution was kept at $2 \mathrm{~cm}^{-1}$ and the no. of scan was 30 times. The major peaks are in the region of $1710.89 \mathrm{~cm}^{-1}$ and $2925.10 \mathrm{~cm}^{-1}$. So FTIR spectroscopic analysis shows that the main functional groups of pithraj seed oil are carboxylic acid $(\mathrm{C}=\mathrm{O})$ appears as main peak in $1710.89 \mathrm{~cm}^{-1}$ region and alkanes $(\mathrm{C}-\mathrm{H})$ that appears in $2853.73-2925.10 \mathrm{~cm}^{-1}$ (Table V).

\section{Functional group analysis of Pithraj seed oil bio-diesel}

Functional group analysis of the obtained bio-diesel was determined by the same method (Fig. 6) which was performed for pithraj seed oil. The ratio of $\mathrm{KBr}$ and bio-diesel was 100:0.1. Major peaks are at $1743.68 \mathrm{~cm}^{-1}, 2854.70 \mathrm{~cm}^{-1}$ and $2929.06 \mathrm{~cm}^{-1}$. So the main functional groups of pithraj seed oil biodiesel are ester $(\mathrm{C}=\mathrm{O})$ appeared in $1743.68 \mathrm{~cm}^{-1}$ and $\mathrm{sp}^{3}$ alkyl (C-H) that appears in 2800-3000 $\mathrm{cm}^{-1}$ region (Table VI).

\section{Thermo-gravimetric analysis}

Thermo-gravimetric Analysis is a technique in which the mass of a substance is monitored as a function of temperature or time 
as the sample specimen is subjected to a controlled temperature program in a controlled atmosphere. An alternative definition of TGA can be stated as, TGA is a technique in which upon heating a material, its weight increases or decreases. A simple TGA ent. A TGA thermal curve is displayed from left to right (Fig.7). The descending TGA thermal curve indicates a weight loss occurred.

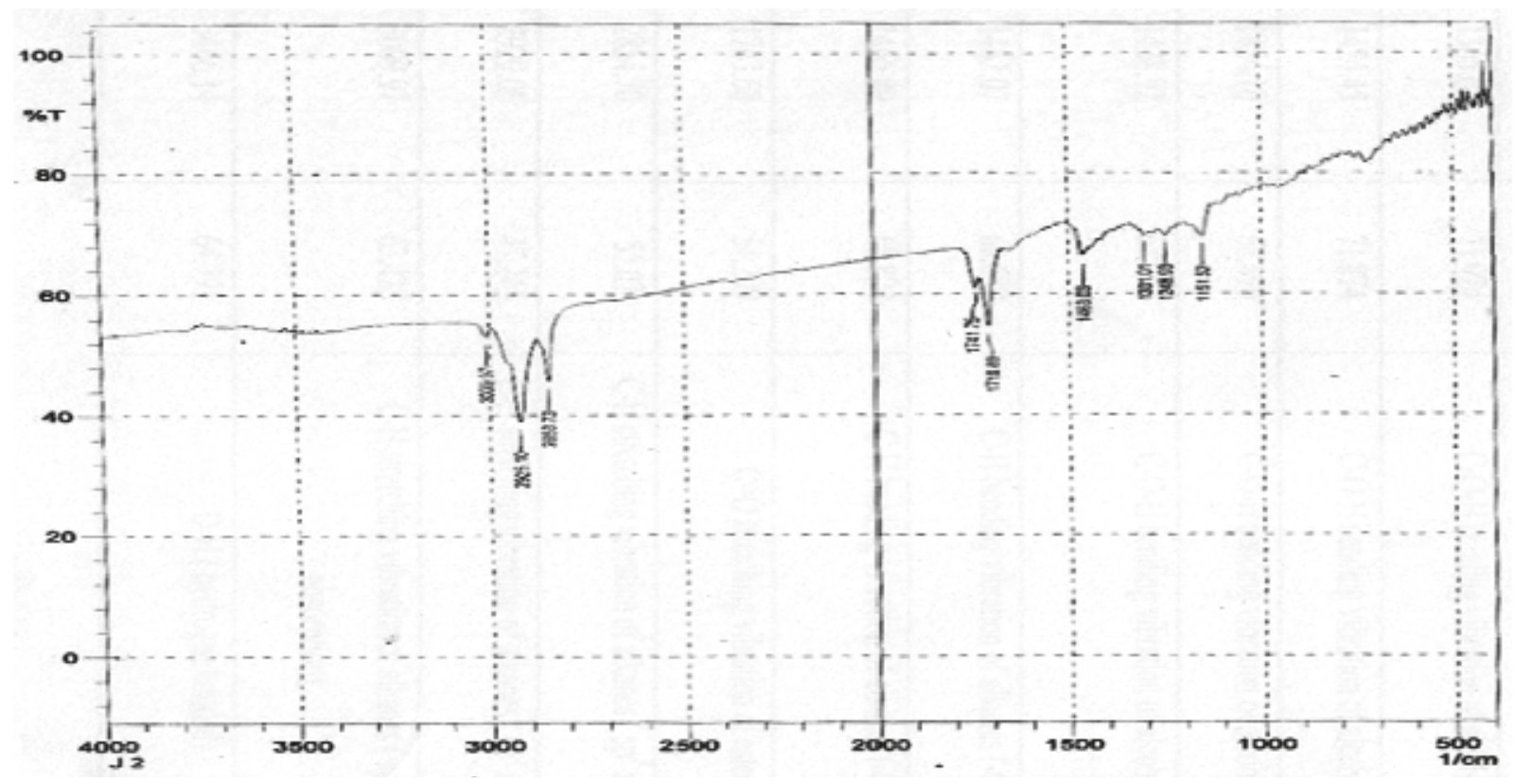

Fig. 5. FTIR spectra of pitraj seed oil

concept to remember is TGA measures a sample's weight as it is heated or cooled in a furnace. In TGA, a derivative weight loss curve is used to tell the point at which weight loss is most appar-
The results from TGA experiments of produced biodiesel are shown in the temperature vs. TGA \% curve in a wide temperature range $\left(40-600{ }^{\circ} \mathrm{C}\right)$. At higher temperatures

Table V. Analysis of peak obtained in FTIR of pithraj seed oil

\begin{tabular}{ccc}
\hline Wave number of peak & Transmittance & Functional group \\
\hline 1151.52 & 69.503 & C-O stretching vibration of ester \\
1248.93 & 69.791 & C-O stretching vibration of ester \\
1301.01 & 69.861 & C-O stretching vibration of ether \\
1463.03 & 66.183 & C-H bending vibration of alkanes \\
1710.89 & 54.688 & C=O stretching vibration of carboxylic acid \\
1741.75 & 61.068 & C=O stretching vibration of aliphatic ester \\
2853.73 & 45.753 & C-H stretching vibration of alkanes \\
2925.10 & 38.937 & C-H stretching vibration of alkanes \\
3009.97 & 53.046 & C-H stretching vibration of alkenes
\end{tabular}




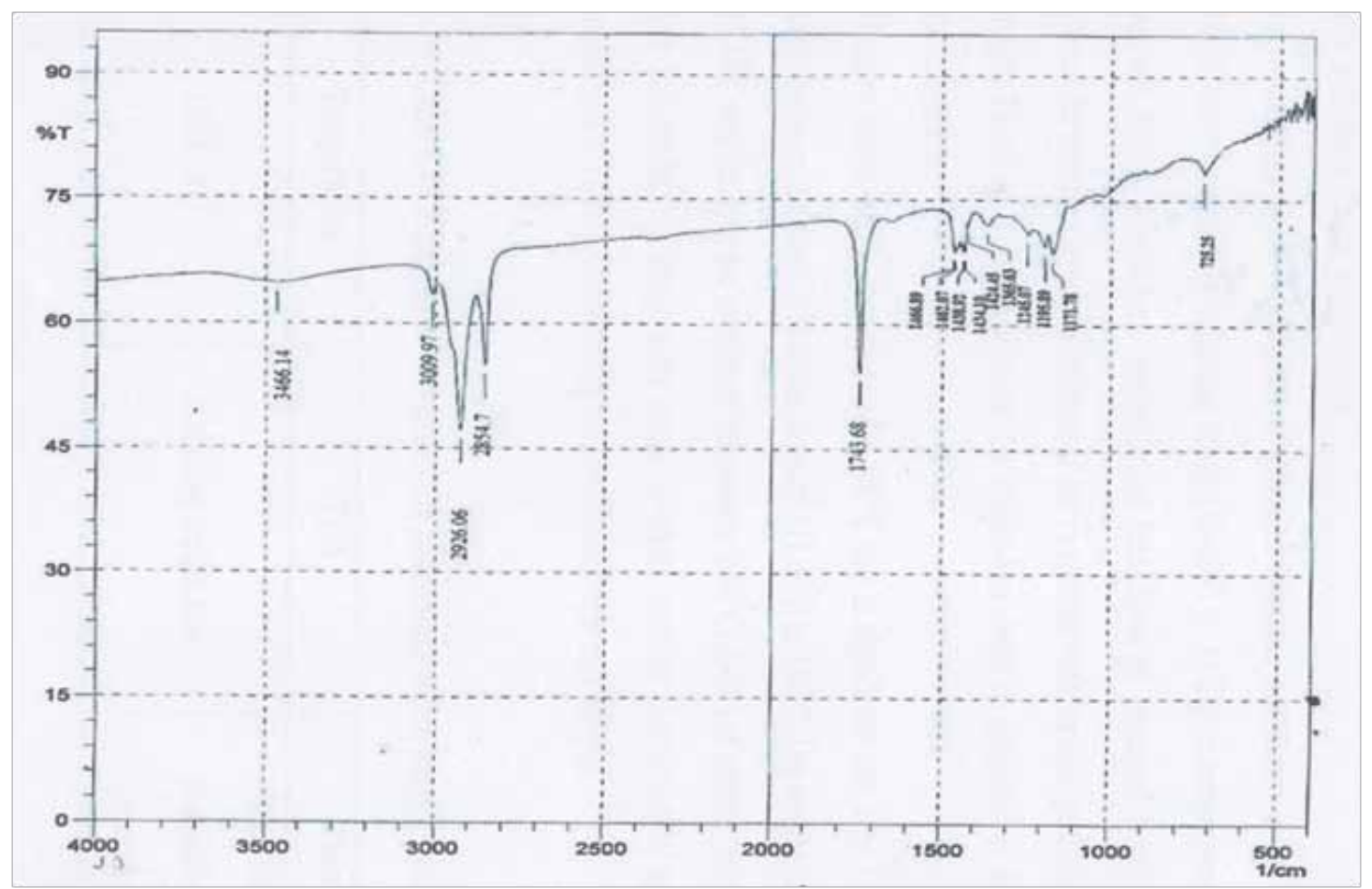

Fig. 6. FTIR spectra of produced bio-diesel from pitraj seed oil

Table VI. Analysis of peak obtained in FTIR of pithraj seed oil bio-diesel

\begin{tabular}{|c|c|c|}
\hline Wave number of peak & Transmittance & Functional group \\
\hline 725.25 & 78.19 & $\mathrm{C}-\mathrm{H}$ aromatic bending vibration ( for mono sub'd ring) \\
\hline 1171.78 & 68.552 & $\mathrm{C}=\mathrm{O}$ stretching vibration for alcohols \\
\hline 1195.89 & 69.364 & C-O stretching vibration of esters \\
\hline 1245.07 & 70.834 & C-O stretching vibration of esters \\
\hline 1365.63 & 71.924 & $\mathrm{C}-\mathrm{O}-\mathrm{H}$ bending vibration of alcohols \\
\hline 1424.45 & 71.874 & $\mathrm{C}-\mathrm{O}-\mathrm{H}$ bending vibration of alcohols \\
\hline 1434.10 & 68.699 & $\mathrm{C}-\mathrm{O}-\mathrm{H}$ bending vibration of alcohols \\
\hline 1438.92 & 68.792 & $\mathrm{C}-\mathrm{O}-\mathrm{H}$ bending vibration of alcohols \\
\hline 1462.07 & 68.682 & $\mathrm{C}-\mathrm{H}$ bending vibration of alkanes $\left(-\mathrm{CH}_{2}-\right)$ \\
\hline 1466.89 & 68.804 & $\mathrm{C}-\mathrm{H}$ bending vibration of alkanes $\left(-\mathrm{CH}_{2}-\right)$ \\
\hline 1743.68 & 54.209 & $\mathrm{C}=\mathrm{O}$ stretching vibration of esters \\
\hline 2854.70 & 55.02 & $\mathrm{C}-\mathrm{H}$ stretching vibration of alkanes ( $\mathrm{sp}^{3}$ absorption) \\
\hline 2929.06 & 47.245 & $\mathrm{C}-\mathrm{H}$ stretching vibration of alkanes ( $\mathrm{sp}^{3}$ absorption) \\
\hline 3009.97 & 63.423 & $\mathrm{C}-\mathrm{H}$ stretching vibration of alkanes ( $\mathrm{sp}^{2}$ and $\mathrm{sp}$ absorption) \\
\hline 3466.14 & 64.791 & $\mathrm{O}-\mathrm{H}$ ( hydrogen bonded) \\
\hline
\end{tabular}


$\left(>400{ }^{\circ} \mathrm{C}\right)$, all materials display weight-loss, involving the breakdown of structural bonds. The similarity between the onsets of structural collapse is put in contrast with variable positions of evaporation process. Therefore in this experiment the weight-loss could be attributed to the breakdown of structural bonds. as a substitute of diesel. Bangladesh does not have any petroleum resources, so this type of renewable fuel will be very helpful to solve our present fuel oil crisis.

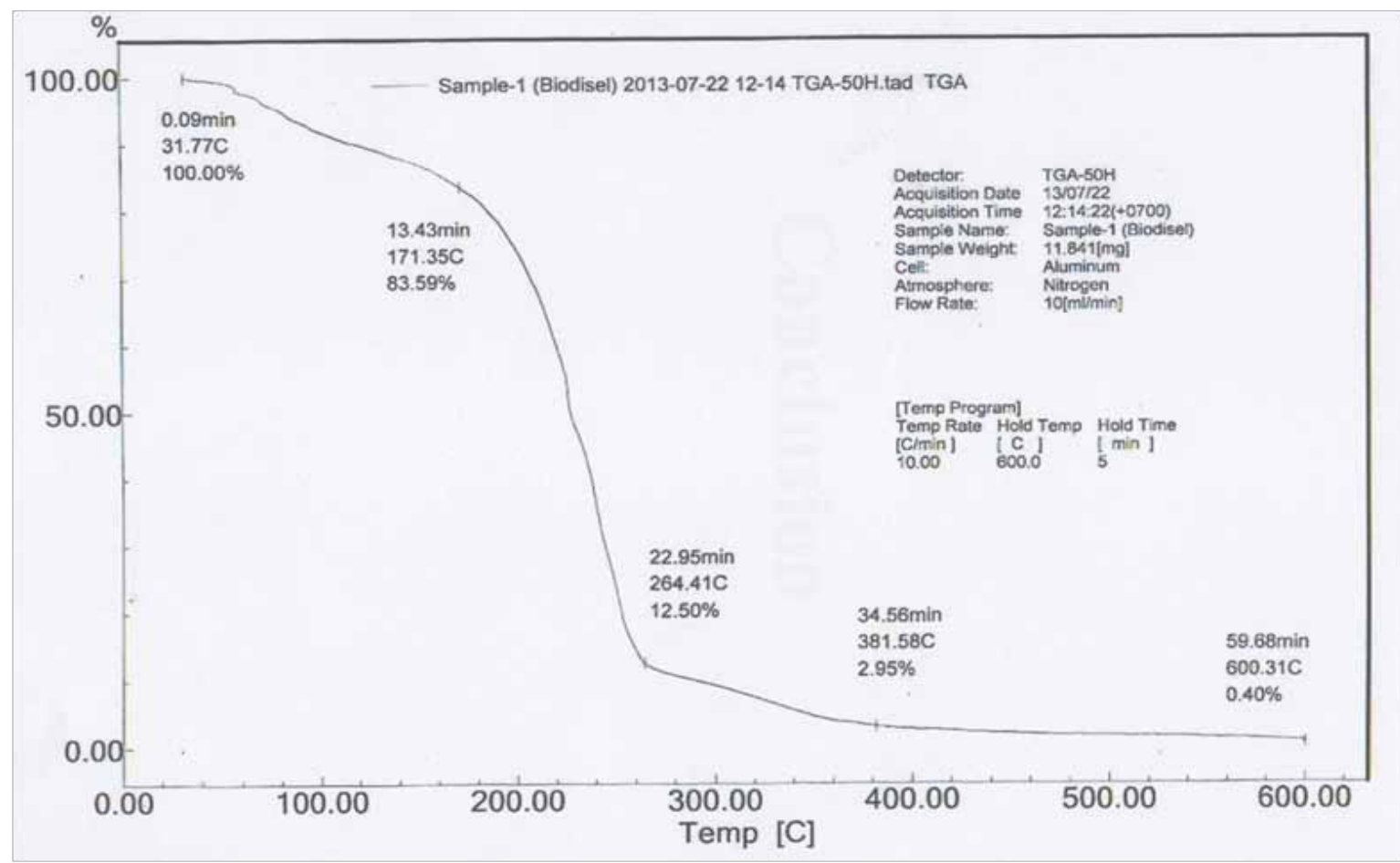

Fig. 7. Thermo Gravimetric Analysis (TGA) of produced bio-diesel

TGA curve (Fig. 8.) shows weight loss starts after $100{ }^{\circ} \mathrm{C}$ and in significant rate after $170{ }^{\circ} \mathrm{C}$. Maximum weight loss occurs almost $71 \%$ in the range of $171{ }^{\circ} \mathrm{C}$ to $264{ }^{\circ} \mathrm{C}$. The weight becomes steady at $381{ }^{\circ} \mathrm{C}$ and finally at the maximum temperature $\left(600^{\circ} \mathrm{C}\right) 0.40 \%$ of sample remains.

\section{Conclusion}

The Pithraj tree is available in different parts of Bangladesh. Particularly it abundantly grows in Bangladesh. The percentage of oil in its seed is higher (50\%) compare to other non-edible seeds of bio-diesel such as rubber (31.8\%) seed. The optimum condition for transesterification is $40 \%$ ethanol and $0.45 \% \mathrm{KOH}$ catalyst and the reaction temperature and time is $75{ }^{\circ} \mathrm{C}$ and $1.5 \mathrm{hrs}$ respectively. The physicochemical properties of the base oil are correspond to diesel except acid value and sulphur content. But after transesterification the oil became suitable to use

\section{References}

Anonymous, Plunkett's automobile industry almanac (2008), Automobile, truck and specialty vehicle industry market research, statistics, trends \& leading companies, Huston (Texas), Plunkett research Ltd.

Balat $M$ and Balat H (2009), Recent trends in global production and utilization of bioethanol fuel, App. Energy, 86: 769-778.

Balat $M$ and Balat M (2009), Political economic and environmental impact of biomass based hydrogen, Int. J. Hydrogen Energy, 34: 3589-3603.

Chhetri AA, Tango MS, Budge SM, Watts KC and Islam MR (2008), Non-edible plant oils as new sources for bio-diesel production, Int. J. Mol. Sci., 9: 169-180. 
Demirbas A (2008), Bio-fuels sources, bio-fuel policy, bio-fuel economy and global bio-fuel projections, Energy Convers. Manage, 49: 2106-2116.

Dorain JP, Franssen HT and Smbeck DR (2006), Global challenges in energy, Energy Policy, 34: 1984-1991.

Goldemberg J (2008), Environmental and ecological dimensions of bio-fuels, Int. Conference on the ecological dimensions of bio-fuels, Washington (DC).

Gui MM, Lee KT and Bhatia S (2008), Feasibility of edible oil and vs non-edible oil vs waste edible oil as bio-diesel feed stock, Energy, 33: 1646-1653.

International Energy Agency (IAEA) (2008), Key world energy statistics, OECD/IAEA, Paris.
Namasivayam AM and KorakianitisT, Crookes RJ, BobManuel KDH and Olsen J (2010), Bio-diesel: Emulsified bio-diesel and dimethyl ether as pilot fuels for natural gas fuelled engines, Appl. Energy, 87: 769778.

Wstermann P, Jorgensen B, Lange L, Ahring BK and Christensen $\mathrm{CH}$ (2007), Maximizing renewable hydrogen production from biomass in a bio/catalytic refinery, Int. J. Hydrogen Energy, 32: 4135-4141.

World Business Council for Sustainable Development (WBCSD) (2004), Mobility 2030: meeting the challenges to sustainability, The sustainable mobility project, Geneva (Switzerland).

Received: 08 January 2014; Revised: 15 December 2014; Accepted: 22 December 2014. 